sufficient and become less bashful and more comfortable in their attitude toward librarians and the library, once it has been overtly demonstrated that the library is actively seeking to help them in their studies. Such a program relieves some recurring problems in public service departments, enhances the library's image on campus, and the staff involved has the satisfaction of introducing a number of foreign students to a very American aspect of their education, as well as contributing to their adjustment in a new and sometimes confusing environment.

Letters of appreciation from the head of Lockwood and the Director of the University Libraries are sent to all the volunteers.

\title{
Financial Restrictions in Academic Libraries
}

\author{
Kay F. Jones \\ Head of Reference Department \\ Zimmerman Library \\ University of New Mexico
}

Spring is budget time in academic libraries. All around us can be heard mutterings about cuts in book budgets, frozen positions, and other financial restrictions imposed on us by the university, the state legislatures, or other budget authorities. It is fair to assume that many librarians wonder how widespread the cuts are in other academic institutions. Are we the only ones who have been hurt?

A survey was sent to 28 directors of libraries in the western third of the United States and sixteen responses $(57 \%)$ were returned. Eleven of the responding libraries were ARL libraries; the other five were one of the three largest university libraries in their states. The survey was designed to find out how widespread financial restrictions were in the West, the nature of these restrictions, and what creative solutions had been invented. Only three of the respondents reported no financial restrictions at all; thirteen libraries $(81 \%)$ had been cut in some way.

Seventy-five per cent of the university librarians or their representatives whose libraries have experienced financial restrictions in the past four years expressed the opinion that the cuts in book budget, reductions in staff, and other restrictions imposed were temporary in nature, although some defined "temporary" as four to six years or longer! One less optimistic librarian commented that unless the financial situation improved in his state, libraries would experience long and permanent financial restrictions such as have not been seen in the state for more than forty years.

Ten of the libraries surveyed $(62.5 \%)$ have had their book budgets cut or have had book funds taken back by the university administration during the fiscal year. Six of the responding libraries experienced no book budget cuts; three others were cut by less than one per cent. Cuts at the other libraries ranged from $2 \%$ to $25 \%$ of the total book budget. Four libraries were cut by $2 \%$ to $8 \%$, making this range the most common. Three libraries were cut by more than $20 \%$. In dollar amounts, the cuts ranged from around $\$ 5,000$ to $\$ 750,000$.

All of the libraries experiencing financial restrictions had some sort of staffing restrictions. The most common form of restriction was frozen positions or a temporary prohibition against filling positions open through attrition. Eight of the libraries responding (half the respondents) had frozen positions. Some of the affected positions were faculty or professional librarian positions; some were staff. Some libraries had a freeze on both classifications. Four libraries had positions permanently reduced. Counting these two areas together, the cuts ranged from one position cut or frozen to one library which had experienced more than thirty lost positions since 1979/80. Two libraries had one affected position; three had two; only two libraries had reductions of more than ten positions. One library said staff had been affected but did not specify a number. For cuts expressed in percentages of the total staff, see Table 1.

Several libraries experienced the double whammy of cuts in both the book budget and in the staff. Eight libraries, or half of the sample, had financial restrictions in both areas.

What has been the result of these cuts on the academic libraries surveyed? Many have responded by cutting services in some way. The most common method employed was a reduction of hours of service; six libraries, $37.5 \%$ of the respondents, used this way to lighten the load on a reduced staff. One library postponed the construction of a new library addition, another postponed the occupation of a new branch, and a third closed two branches and reabsorbed the collections into the main library. Reference services have been reduced, bibliographic instruction has been curtailed or eliminated, and areas such as Special Collections or Audiovisual Services have been reduced or eliminated. One librarian commented that no growth in grossly underfunded areas could be considered a cut.

The question was asked of these librarians, "Have you considered or conducted a systemwide review of operations to identify areas in which to economize?" Two libraries include this as part of 
TABLE 1

FINANCIAL RESTRICTIONS

\begin{tabular}{cccc}
\hline \hline \multicolumn{2}{c}{ Book Budget Cuts } & \multicolumn{2}{c}{ Staff Cuts } \\
\hline Cut & $\begin{array}{c}\text { Number of } \\
\text { Libraries }\end{array}$ & $\%$ Cut & Number of \\
Libraries \\
0 & 6 & $<1$ & 3 \\
$<1$ & 3 & $1-2$ & 3 \\
$2-8$ & 4 & $3-4$ & 2 \\
$9-19$ & 0 & $5-7$ & 2 \\
$20-25$ & 3 & 8 & 1 \\
$25+$ & 0 & 24 & 1 \\
\hline
\end{tabular}

their ongoing budgetary procedures; department heads are involved in the process. Only five other libraries responded that they have instituted special reviews as a result of the financial restrictions. Three of these libraries have set up task forces or committees to examine a broad range of services to determine where economies might be instituted, one library is conducting a "manpower evaluation" but did not delineate the methodology, and one other library commented that the reductions pattern had been achieved by a cost analysis approach.

Changes in the goals and objectives at the university level do not often affect the library's goals and programs, according to respondents. One librarian asked, "How many universities have defined their goals?" Another commented that the goals of the university were presently under review and that the library would react appropriately when the review was completed. Four other libraries have responded to changes in curriculum, such as additional emphasis on business or high technology, by adding collection development specialists in those areas and changing library priorities to support the new programs.

Even fewer librarians had creative innovations to share. Two cited automation of services as a help, one mentioned increased income through the photocopying service, two have introduced user fees, and one has sought additional grants. One librarian credits his dedicated staff for their survival and adds that they have relied on "prayer, profanity and perseverance."

It is clear from even this limited survey that most academic libraries are experiencing financial restrictions. No one can accurately predict how long these restrictions may last, although the sample surveyed reported feelings of optimism that the limitations were temporary in nature. However, ten of the respondents, $62.5 \%$, said the "temporary" restrictions would last at least two years. If this is true, it is surprising that so few of the libraries have closely examined their organizations to determine if economies could be instituted to save money. Few creative innovations have been developed to reduce costs in some meaningful way. Hours have been reduced and other services have been cut in order to cope with staffing shortages. Wouldn't we be doing our academic communities a service if we were to analyze the total picture of library services to determine a balanced and reasonable way to live within our reduced budgets?

\section{Reference Transaction Survey Begins Field-Testing}

A survey instrument, designed to collect reference transaction data on computer scannable sheets, was introduced and distributed to interested libraries at the conclusion of the LAMA Statistics for Reference Services Committee program at ALA Annual Conference in Los Angeles. This survey, a special project of Marjorie Murfin and Charles Bunge, has been approved for field-testing in academic libraries by LAMA in order to determine if such a survey is feasible and useful.

Tentative data may be obtained, by use of this one-day survey, to compare a library's reference service with reference services in other libraries of the same size and type in regard to: 1) subject and type of questions and by whom asked; 2) type of personnel responding, type of response, search patterns and problems encountered; 3) success of this response in terms of patron and librarian ratings; 4) patron report of amount learned in connection with the transaction.

Interested academic libraries may obtain a packet of forms and materials free of charge for examination and consideration, without obligation to do the survey. All that is asked is that packets be returned if not used. Packets may be obtained from: Marjorie Murfin, Reference Department, Main Library, 1858 Neil Ave. Mall, Columbus, OH 43210. 